\title{
UNASUR and the state-centric perspective of security in South America $^{*}$
}

\author{
Sergio Caballero**
}

\begin{abstract}
Over the last few decades we have witnessed an emerging interest in security topics and mechanisms to analyse these. In the context of globalization, new threats have appeared (not only interstate, but mainly, intra- and trans-state), as well as theoretical approaches (such as Critical Security Studies, CSS) to deal with them.

Regarding the South American region it is useful to consider the constitution of the Unasur as a forum to coordinate policies with a very relevant geostrategic and security influence. In this paper, I deal with the logics that motivated the birth of the UNASUR project, in order to examine the way this regional project acts against different types of security threats and regional crises until 2016-17, when Venezuelan crises escalated. Furthermore, empirical evidences are tested with the common characteristics proposed by Peoples and Vaughan-Williams for the CSS.

Some conclusions are drawn as new aspects have been incorporated to the way UNASUR addressed regional conflicts (security as a derivate concept and a broader security agenda), while an important element remained the same: a state-centric perspective.
\end{abstract}

Key words: UNASUR - security - regionalism - Critical Security Studies - state-centrism

\section{UNASUR y la perspectiva estadlocéntrica de seguridad en Sudamérica}

\section{Resumen}

En las últimas décadas hemos asistido a un creciente interés por los temas de seguridad y cómo analizarlos. En el marco de la globalización, han surgido nuevas amenazas (no sólo interestatales, sino también intra- y trans-estatales), así como nuevos enfoques teóricos para abordarlos (como los Estudios Críticos de Seguridad, CSS).

En lo que concierne a la región sudamericana resulta oportuno entender el surgimiento de la UNASUR como un foro de coordinación de políticas con una importante relevancia geoestratégica y de seguridad. En este trabajo, se abordan las lógicas que motivaron el nacimiento de la UNASUR, con la intención de analizar cómo este proyecto regional se ha comportado ante los distintos tipos de amenazas de seguridad y las crisis regionales hasta el año 2016-17 con la escalada de la crisis venezolana. Además, se evalúan y testan las evidencias empíricas en contraste con las tres características comunes de los CSS que señalan Peoples y Vaughan-Williams.

Finalmente, se extraen algunas conclusiones sobre las nuevas particularidades y prácticas que la UNASUR ha introducido a la hora de lidiar con conflictos regionales (seguridad como concepto derivativo y la ampliación de la agenda de seguridad), mientras que, por el contrario, el tercer componente permanecía igual: una perspectiva estadocéntrica.

Palabras clave: UNASUR - seguridad - regionalismo - Estudios Críticos de Seguridad - estadocentrismo

TRABAJO RECIBIDO: 05/10/2018ＴRABAJO ACEPTADO: 03/06/2019

\footnotetext{
* I would like to thank the blind referees for their comments and suggestions. However, the mistakes still remaining in the article are just my responsibility. This article is based on previous researches developed by the author on regionalism and interregionalism from critical theories. Some findings have partially been presented in academic congresses and drafted in Spanish but this paper is the updated-and-improved last version (https://deusto.academia.edu/SergioCaballero https://www.researchgate.net/profile/Sergio_Caballero4).

** $\mathrm{PhD}$ in International Relations, Department of International Relations. Vice-Dean for Research and International Relations, Faculty of Social and Human Science, University of Deusto (Spain). E-mail: sergio.caballero@deusto.es
} 


\section{Introduction}

Over the last few decades we have witnessed an emerging interest in security topics and mechanisms to analyse them (Williams, 2008; Hughes \& Meng, 2011). In the context of globalization, characterized by a wide and fast spread of thoughts and the necessity of being part of a globalized world, new threats have appeared (not only interstates, but mainly, intra- and trans-states), as well as new strategies to solve them out. Critical Security Studies (CSS) have modified both the scope and the depth of the "security" concept within the International Relations.

In the specific case of Latin America security, historically intrastate issues have always dominated the security agenda. At the same time, we are witnessing nowadays attempts to frame some of the security problems in regional and subregional terms through ALBA, UNASUR, and CELAC (Kacowicz \& Mares, 2016:27).

In this paper firstly the emergence of the aforementioned CSS is exposed, highlighting their potentialities and their contribution in relation to other approaches. Afterwards I deal with the logics that motivated the birth of the UNASUR project - understood as a forum to coordinate politics with a very relevant geostrategic and security influence- in order to examine the way this mechanism acts against different types of security threats. Thus, I focus on the extension of the concept of threat from interstate conflicts to intrastate conflicts -such as political turmoil, democratic stability or coup d'état- and trans-state ones -i.e. environmental risks or international crime organizations, among others-.

Indeed, following Peoples and Vaughan-Williams (2010:23-24), our analyse of the security concept in relation to the UNASUR will tackle the three main characteristics shared by the CSS: (i) security as a derivative concept, thus a changing idea depending on how we understand the world; (ii) the existence of a broader security agenda, apart from national defence and sovereignty; (iii) the challenge of going beyond the assumption of the state as the unique "referent object of security". And as a corollary it is inferred the will to transform the reality, that is, the normative dimension of these CSS.

After having studied our case -UNASUR- through the CSS prism, the first two characteristics have been rightly proved as having been applied in some empirical cases in South America, whereas the state-centric approach remained powerful in the region as seems evident when dealing with the progress and setbacks of Latin American regional integration (Caballero, 2015).

The aim of this paper will not be an analysis of UNASUR performance nor to explore the suitability of UNASUR participation to deal successfully with regional crises. The focus will be on how the idea of security has been modified in the region, partially thanks to the conceptual improvements developed within UNASUR. Furthermore, the ongoing crisis in Venezuela as well as the collateral effects concerning UNASUR, where 6 out of the 12 members have suspended their membership leaving the mere existence of the organization at stake, is not tackled here although it is a current topic in the field ${ }^{1}$.

\section{Emergence of Critical Security Studies (CSS)}

The meaning of security has always been debated and its precise definition has been changing in time depending on the academic and historical context (Buzan \& Hansen, 2009). A quick theoretical overview is presented here. Firstly, security studies have traditionally understood security in terms of material power and the defence of national sovereignty. This vision, which was configured as the mainstream of the discipline during the Cold War,

\footnotetext{
1 As proved by the proliferation of scientific panels and papers on the UNASUR crisis due to the Venezuelan conflict as well as the South American regionalism disintegration in the last Latin American Studies Association (LASA) academic congress held in Boston (USA), in May 2019 (Last access June $\left.4^{\text {th }}, 2019\right)$. Retrieved from https://lasaweb.org/uploads/lasa2019-program-final_es.pdf
} 
emphasizes a military approach and under the label of Strategic Studies put the focus on national security (Wolfers, 1952:481-502). The idea of security linked to power and the survival of the state in an anarchical world is obviously derived from the dominant theory in International Relations, the (neo-) realism. Furthermore, these logics of vulnerability, emergency and nuclear threat were strengthened by the behaviourist revolution, which took place within the social sciences during the Cold War. To sum up, the combination of a historical context of antagonism between two superpowers and the consolidation of new scientific approaches constrained the ways that security could be conceived, fostering a definition of security linked to national sovereignty, military defence and strategic calculation.

However, when the Cold War was coming to its end in the 80's, the emergence of new theoretical approaches and the reflectivist turn stimulated complexity and theoretical development of the security concept. Indeed since the 80's new actors (NGO's, international companies, civil society, epistemic communities...) gathered momentum concerning security threats and moved these issues out of the exclusive realm of the states. Meanwhile new challenges and risks entered into the security agenda, as the Copenhagen School proved through their securitization approach (Buzan, Waever, de Wilde, 1998). Following this process of securitization, there are issues which are susceptible of being included in the security agenda on account of performative acts of speech and the relevance conferred to them by some experts as well as by the general audience. Thus, this movement from the political realm (where situations are "normally" regulated) to the security agenda (where extraordinary and urgent measures are adopted) is provoked by a communicative act and the way it is interpreted. In conclusion, the securitization process implies a performative act because it produces a new perception of threat and classifies an event as an affair not just political but mainly as a menace concerning security ${ }^{2}$.

Nevertheless, "the emergence of the CSS did not mean the end of the Strategic Studies. [Stephen] Walt supported the renaissance of the traditional studies based on the new threats posed to the state's foreign policies (Walt, 1991). Whereas the CSS were spreading over the European academy, the Strategic Studies remained the mainstream in the American research centres (Waever, 2004)" (De la Flor, 2012:5). In fact, both visions have coexisted in the last decades, being one or the other more suitable depending on the focus and, notably, depending on the researcher's departing point; that is, if it is applied a state-centric approach linked to national security, or if the individual is emphasized, so linked to a human security with close ties with development and well-being.

In relation to this very last argument, the conceptual contribution coming from the United Nations Development Programme (UNDP) is remarkable. In its 1994 report $^{3}$, they coined the term "human security", broadening the aspects concerning security and linking it tightly to the individual, at the same time that a distinction between "freedom from want" and "freedom from need" was theoretically developed. It should not be forgotten the proliferation of these concepts -human rights, democracy, positive peace...- after the end of the Cold War, as well as the intention of Western countries to spread them to other regions through "humanitarian interventions" and/or applying the postulates of the democratic peace thesis.

However, the September 11 attack arose as a turning point concerning security studies. On the one hand, security issues came to the top of the political agenda, affecting both foreign policy and domestic affairs debates. In certain way, this event resituated the security concept in the traditional national dimension, strengthening the idea of order and protection that the states have always claimed for them. On the other hand, against this Neorealist perspective, new

\footnotetext{
${ }^{2}$ Inversely, a process of de-securitization is also possible when an issue is not anymore considered a security issue, guided by exceptionality, but it is reassumed as a normal issue addressed through daily politics.

3 Report on Human Development, elaborated by the UNDP in 1994. Retrieved from http://hdr.undp.org/sites/default/files/hdr_1994_es_completo_nostats.pdf (last access September 26, 2018).
} 
"schools" developed other concepts of security in both the ontological and the epistemological level (CASE Collective, 2006).

In that sense, apart from the aforementioned Copenhagen School, we find the Aberystwyth School ${ }^{4}$, in Wales, with influences from the Frankfurt School and the idea of conflict and critical theory developed by Robert Cox (Cox \& Sinclair, 1996). Coming from there, they state that the basis of security is the emancipation of individuals and, therefore, neither power nor order are the key element to guarantee security, but emancipation understood in terms of welfare and the absence of domination and constraints. Applying a critical approach, it is underlined how the security concept, limited by the state order and the preservation of the status quo, has been historically used at the expense of emancipatory possibilities.

Indeed, the extension of the meaning of security and the inclusion of new threats -such as poverty or social exclusion- in a more comprehensive definition, could provide room for further changes in the real world. As it seems obvious, this approach is highly normative and aims to elaborate a prescriptive theory which could have influence in the empirical arena. And this emancipatory goal is paramount, although it is not defined how it could be applied into reality and, in addition, how someone could reach a total emancipation without provoking new forms of domination upon "others".

Finally, the Paris School ${ }^{5}$, in debt to political sociology in general and authors such as Foucault and Bourdieu in particular, tackles security from a broader perspective than the International Relations discipline. This approach is mainly focused on practices, on contexts and on daily acts and resistance behaviours, rather than a specific international event nor a speech act. Therefore, their research agenda deals with the professionals of security, the agents who apply and deliver (in)security and the technological devices deployed to control the population. Following this argument, one of the main concepts would be governmentality, understood as a way to control people's practices.

Although several nuances and specificities arise from each one of these critical approaches to security, it can be stated that these CSS could act in a complementary way, fading away their respective differences among the Paris, Aberystwyth and Copenhagen Schools (CASE Collective, 2006). To exemplify these meeting points, I highlighted three shared characteristics (Peoples\& Vaughan-Williams, 2010:23), which I will test within our study case: (i) security as a derivative concept; or in other words, security is not an unequivocal term, but its meaning depends on the ontology from where you depart. For example, from the dominant neorealist vision of International Relations, if the world is understood as a system of international anarchy, composed by interacting units -rational, homogeneous and unitary states, which strengthen their material capacities in order to succeed in a cyclical struggle for survival, the security would be linked to the protection and conservation of that "billiard ball" i.e. national sovereignty- in face of threats coming from "outside".

On the contrary, if applying other approaches tied to an ontology closer to individuals, such as international political sociology, or an ontology based on a "world socially constructed", such as constructivism, just to give a couple of examples, security would be perceived in a very different way. Thus, respectively it would be attached to the individual protection and/or welfare (even against the very national state) or it would be attached to our own perceptions of the threats and the psychological construction of the "other" as friend or foe.

Secondly, (ii) the existence of a more comprehensive security agenda is a common characteristic which leads us beyond material capacities. In this case, security is not just about territorial integrity, where the military dimension could be decisive, but also other "sectors" are quite relevant, for example, environmental risks, political and socio-economic challenges... In certain way, the number of threats is increased because of the rising range of common goods

\footnotetext{
${ }^{4}$ The Aberystwyth School is integrated by authors such as Ken Booth or Richard Wyn-Jones, among others.

${ }^{5}$ Authors as Didier Bigo or Jef Huysmans are actively participating within this Paris School.
} 
expected to be protected, from democratic stability to human rights and health, and also including environmental protection and sustainable development.

And, lastly, the third characteristic (iii) is related to the assumption of the state as the "referent object of security". In this sense, having recognized that the CSS aspire to overcome the state-centric perspective ${ }^{6}$, these critical approaches agree that the state cannot be the unique and central element, though they disagree about the ones who have to be secured and protected: the individual as a human being, the community, our society, "us", every life within the planet...

As stated by Tickner and Herz, "contrary to human security discourse, however, democratic security never identified human beings as its object of study. The fact that human security has never been widely embraced by Latin American scholars points to its essential misfit with regional approaches that are by nature statist and are part of the region's longstanding tradition to view the state as an agent of modernization" (Tickner and Herz, 2012:105). Furthermore some scholars will propose a decolonial approach not just to hypothetically incorporate non-humans as referent objects of security but rather to explore the potentialities of the pluriverse, instead of a "one-world world" (Blaney \& Tickner, 2017).

Once I have quickly presented these theoretical perspectives on security studies inside the International Relations discipline, I will explain the origins of UNASUR and how the security concept fits into this regional entity, at least until 2016-7 when the liberal-conservative shift in Latin America (Sanahuja, 2019), together with the ongoing Venezuelan crisis escalated even more generating regional outcomes, including a humanitarian crisis in their borders. I stress our interest on the conceptual development at the regional level, rather than the specific debate about who tackles these threats, such as transnational crime or if the measures taken are strictly bilateral and not regional ${ }^{7}$. Additionally I argue from the beginning that the UNASUR is born not just to face traditional threats -as interstate classic wars- or to deal with security just in material terms. On the contrary, from its birth the UNASUR would enjoy a broad security agenda ${ }^{8}$ while trying to solve out old and new threats along the security field.

\section{UNASUR and the concept of security}

The origins of the UNASUR date back to the emergence of the South American Community of Nations (CSN), which was created by the Cuzco Declaration in 2004. The initial objective was to join every South American country in a sort of Andean Community (CAN) plus Mercosur plus Chile, Guyana and Surinam. In other words, "in this summit the three initial elements for a South American regional project are established. The first one is the coordination of foreign policies, in order to confirm South America as a regional group in the international arena. The second one is the convergence of the CAN, Mercosur, Chile, Guyana and Surinam in a South American Free Trade Area. And the third one is the energetic, telecommunications and physical integration of South America through the IIRSA" (Sanahuja, 2011:124-125; 2007:20).

This project was led from Brasilia and it was designed following the main lines drew by Brazilian president Fernando Henrique Cardoso during the first South American Presidents Summit in 2000. Since then, Brazilian Ministry of Foreign Affairs -Itamaraty- made a terminological shift and started talking about South America, as the natural geographical region for Brazil, instead of Latin America, thus excluding Central America and, more significantly, México.

\footnotetext{
${ }^{6}$ It is important to point out that the securitization theory coming from the Copenhagen School does affirm a statist point of view, even if they introduce other relevant actors. On the contrary, approaches coming from Aberystwyth and Paris firmly opposed any state-centric perspective.

${ }^{7}$ In this sense, on the lack of a coherent regional structure to deal with collective security, see among others Muggah \& Diniz (2013:19).

${ }^{8}$ Other authors, even if they are not clearly situated under the umbrella of the CSS, stress the expansion of the security concept (Battaglino, 2008:25-27).
} 
Afterwards, the evolution from the CSN to the Union of South American Nations (UNASUR) (Briceño Ruiz, 2010:103-121) made clear the relevance of Venezuelan president Hugo Chavez and Bolivian president Evo Morales to redefine some bias of the project. From their position as leaders of the Bolivarian Alliance for the Peoples of Our America (ALBA), both presidents persuaded the other presidents ${ }^{9}$ to broaden the competences of the UNASUR project with a multidimensional scope, including environmental issues, development and energetic issues, social dimension....and, obviously, security issues.

Finally an eclectic position between the leaderships of Venezuela and Brazil was adopted and the UNASUR was configured in 2007 as the minimum shared by all the different presidents and ministries of foreign affairs in South America (Briceño Ruíz, 2010:118). Therefore, in the Isla Margarita Summit in 2007 a new name was chosen, "Unión de Naciones Suramericanas (UNASUR)", and subsequently, in May 2008, the Constitutive Treaty was signed in Brasilia, though it did not get formally into force until March 2011 when the ninth country -Uruguay- ratified it.

It cannot be forgotten other temporary circumstances which contributed to the emergence and development of UNASUR. Concerning geopolitics, the increasing American indifference towards the region gave more room and autonomy for these regional actors and, mainly, to Brazil aspirations of setting the regional agenda. Furthermore, the rise of China as a new economic pole changed some of the traditional rationales in the region.

Indeed, some of the regional economies took advantage from the high prices of commodities and modified their foreign policies in order to build economic bridges to Asian markets. Paradoxically, what seemed a more autonomous region in relation to the United States turned into a reprimarization of the export pattern, implying an increasing dependence to AsiaPacific region and, mainly, to China.

In geopolitical terms, UNASUR behaved as a concentric circle within the Latin American integration ${ }^{10}$. Therefore, starting from the smallest one, that is, the strategic association between Buenos Aires and Brasilia, this close relation acts as a glue to consolidate democracy and regional stability. A good example of this first Argentinian-Brazilian ring would be the "inwards" democratic consolidation developed by Presidents Raúl Alfonsín and José Sarney in the 80's, supported by the "outwards" elimination of the risks of war between these two "antagonistic" countries.

Then, Mercosur played a relevant role in economic as well as socio-political integration. In this sense, the increasing economic interdependence during the 90's took place while developing an incipient political institutional design as well as shared labour regulation or education system.

Moving up in these concentric circles, UNASUR represents a forum for political coordination focused on two main issues: (i) security and stability for the region, and (ii) energy, transport communications and infrastructures, notably through the aforementioned IIRSA $^{11}$, which was launched in the first Summit of South American Presidents, which took place in Brasilia in 2000.

Following this concentric circles' rationale, the next ring would was Community of Latin American and Caribbean States (CELAC), created in 2010 and with diffused objectives.

\footnotetext{
${ }^{9}$ It is indispensable to underline how highly presidentialist Latin American foreign policies are, as scholars such as Sean Burges (2017) have proved.

${ }^{10}$ For a slightly different interpretation of the concentric circles theory posed in this work, see Serbín (2008:142).

${ }^{11}$ In this case, once again, it is suitable to notice not just the wishes, but the logics under these initiatives. Thus, the achievements of a bi-oceanic corridor are in Brazil's intentions to have an easier (and cheaper) access to the Pacific ports in order to increase their exports to Asia. This similar nationalist rationale could be found in the case of the CDS as a platform for developing their military industry while selling more weapons to the regional neighbors.
} 
Indeed, the CELAC acted as a forum where the friendly picture of the "big Latin American family" was taken. These meetings enabled the presidents to know each other and even to solve some bilateral tensions out. However, due to their ideological differences and the lack of any institutional body, their consensuses were just in big themes such as peace promotion or respect to human rights, where no specific measure was taken nor any decision was compulsory. At the end of the day, an important aim for the CELAC was to gain actorness in the international arena, so they could talk as a unique voice, which could be representative of the Latin American leaders (Sanahuja, 2014:75-108). But the lack of accountability made it increasingly inefficient.

After having quickly presented a picture of Latin American regionalism at the beginning of the $21^{\text {st }}$ century, I go back to the security dimension in relation to UNASUR. As some has pointed out, the emergence of UNASUR with a security agenda was remarkable because "that proposal produced a new fact in the hemisphere: for the first time, South American countries discuss a common defence agenda without any extraregional intermediary, notably, without the direct presence of the United States" (Rodrigues \& Rodrigues, 2011:218). The common understanding among some diverse political projects of the region (Caballero, 2011) notwithstanding their ideological differences ${ }^{12}$ - provoked the creation of a specific forum such as UNASUR and, furthermore, the security issues were incorporated as something suitable and valuable for the region itself.

Throughout several meetings of the Ministers of Defence of UNASUR member states, the idea of security understood as broader than mere defence against external material menaces was conceived. In this sense, some new risks and threats were included, such as the case of extreme poverty (Kalil Mathias, Cavaller Guzzi \& Avelar Giannini, 2008:75). This definition process ended in the Summit of Costa do Sauipe, Brazil, in December 2008, where the presidents of the member states of UNASUR approved the statute which created the South American Defence Council (CDS, for its acronym in Spanish). From the beginning, the project launched by Brazilian president Lula da Silva had been supported by all the other governments, except the Colombian one, who perceived it as a sort of reprobation against their military agreements with the United States. Nevertheless, diplomatic negotiations deployed by Brazilian Minister of Defence, Nelson Jobim, and the explicit declaration that this regional mechanism did not intend to interfere in the US-Colombia relations facilitated the definitive creation of the CDS in its first summit in Santiago de Chile, March 2009. The general objectives of the CDS were the consolidation of South America as a peace zone, the development of a South American identity in security affairs and the generation of consensus in order to foster regional cooperation $^{13}$.

\section{Regional crises and security menaces addressed by UNASUR}

Before examining the security concept in the UNASUR context, it would be suitable to mention the main crises and security menaces where UNASUR has participated as an intercessor or as a discussion forum for each part. Meanwhile I will test these empirical facts related to South American conflicts with the aforementioned theoretical characteristics proposed by Peoples and Vaughan-Williams in relation to the CSS approach.

The first event analysed is the one concerning the risk of internal secession in Bolivia in 2008. The case of this domestic crisis, which was motivated by the constitutional reform launched by president Morales, reached its peak with the killing in Porvenir-Pando, September 11, 2008. In this case, UNASUR -indeed, even before having formally entered into forceobtained the political legitimacy to mediate between the secessionists prefects from the eastern

\footnotetext{
${ }^{12}$ One of the strongest examples would be the blockade of the international bridge between Uruguay and Argentina in Gualeguaychú, which launched a deep bilateral conflict between both countries. This tension between presidents Néstor Kirchner and Tabaré Vázquez was increasing from 2005 and it was not moderated until 2010, when two different presidents (Cristina Fernández and José Mujica) were in office. ${ }^{13}$ For more information, see the CDS website: http://unasursg.org/es/node/21 (last access June 3, 2019).
} 
regions and the government of president Morales. This fact becomes even more relevant on account of the place where a paramount Bolivian affair was discussed: the Chilean presidential Palacio de La Moneda, as Chile was holding the rotating presidency of the UNASUR in that second semester of 2008. Therefore, the historical enmity between Bolivia and Chile was partially overcome by UNASUR in order to foster regional stability (Aín, 2012). Furthermore, concerning this crisis, apart from going beyond the classical security agenda of national sovereignty and material defence, the meaning of security is perceived as a derivative concept, i.e., measures for Bolivian stability are taken by an external institution -UNASUR- which has gained enough regional legitimacy -due to the negotiations led by Lula da Silva and Michelle Bachelet-, so the very concept of security has been regionalized.

The second crisis presented is the one related to the American military bases in Colombia, which was tackled in the summit of Bariloche, August 2009. Although the meeting showed a notable regional disagreement on security cooperation, UNASUR was proved as a valid interlocutor where these differences could be settled. Member states, which have previously put pressure on Colombian government, were satisfied after having Colombia stated that the military agreement did not diminish national sovereignty nor territorial integrity of any South American country. So, in this case -and also in the following examined crisis- the security concept is closer to a traditional vision, with a state-centric nuance ("in terms of the referent object of security"), a limited material and defence agenda ("not a broad agenda") and a security approach linked to a neorealist and anarchical international system ("in terms of the derivative concept of security").

The third crisis addressed by UNASUR can also be considered as a "classical" one, that is, an interstate conflict. After the Colombian bombing of a FARC battalion in Ecuadorian soil, an initial friction between Ecuador and Colombia arose. Afterwards, Venezuela regionalized the conflict and continued the escalation. Thus, the declared enmity between presidents Hugo Chávez and Álvaro Uribe, resulted in a bilateral pre-war situation. It is interesting to notice why the Organization of American States (OAS) was not legitimized to intervene as it was perceived as dominated by the USA, so pro-Colombia. Brazil and Argentina took advantage from this situation to give more relevance to UNASUR, with the new general secretary Néstor Kirchner. The former Argentinean president met both Uribe and Chávez in August 10, 2010, and announced a détente between both countries. Although no compulsory decision was taken nor a definitive solution was achieved, UNASUR succeeded at self-presenting once again as a guarantor of peace and regional stability and the only one capable of avoiding a hypothetical aggression between two South American neighbours.

The fourth crisis tackled here deals with the police rebellion and the so-called coup d'état in Ecuador. In September 30, 2010, an internal crisis put president Correa in jeopardy and subsequently, the preservation of democracy and stability in this Andean country. UNASUR promptly convened a presidential meeting in Buenos Aires with the aim of supporting the regional commitment with democracy and, therefore, their political backing to the legitimate president Correa. In order to make even more explicit this support, a meeting among the ministers of foreign affairs of UNASUR member states was set for October $1^{\text {st }}$ in Quito. In conclusion, UNASUR did not just solve this political menace out, but they also took advantage to set a precedent concerning the safeguard of democratic regimes in order to avoid other hypothetical coups in the future in the South American region.

The outcomes of this crisis were quite relevant -and it will be meaningful for the following crisis mentioned below-. In this case, the derivative concept of security meant here the respect for democratic legality. This fact implied an evident extension of the security agenda not just because it was a domestic conflict instead of an interstate one, but also because democracy was regionally protected as a value, as a regional common good. The palpable evidence was the elaboration of a consequent democratic clause for UNASUR member states. Finally, the "referent object of security" was ambiguous. Although the vision was clearly statecentric in this case, it could also be argued that the main -and ultimate- beneficiary of 
democratic stability was the citizenship, the society as a whole, thus it would go beyond the state as the referent object to be protected.

The fifth crisis examined here is related to the removal of Paraguayan president Fernando Lugo in June 2012 due to an impeachment process launched by the legislative branch, coming into office his vice-president Federico Franco. The governments of the UNASUR member states interpreted that the procedure applied had not been legal nor respected democratic guarantees. Therefore, UNASUR, honouring the democratic clause of UNASUR (as well as the Mercosur one)-and also due to the empathy with the outgoing president and other political strategies such as the expected Venezuelan adhesion to Mercosur, which are out of our current scope in this paper-, decided to suspend Paraguay from UNASUR until democratic order was recovered. In April 2013, a new president was democratically elected, Horacio Cartes, and the negotiations to a formal re-entry of Paraguay in UNASUR quickly developed. In the case of this crisis it would be applicable the arguments exposed for the precedent crisis, as it was a domestic issue with regional outcomes, where UNASUR decided to intervene on behalf of democratic values, overcoming the classical limits in terms of security linked to external and material menace.

Lastly, it is worthy to mention a couple of ideas on the ongoing Venezuelan crisis despite the lack of temporal perspective to properly analyse it. After the death of president Hugo Chávez and the electoral victory of his successor, Nicolás Maduro, Venezuela was (and still is) living under a dramatic economic crisis as well as a socio-political one. Since the very first moments of social revolts against the government, UNASUR has been criticised for not being able to bridge mediation channels between the two antagonistic positions inside Venezuela. Even if the Venezuelan crisis could be interpreted as a tour-de-force for UNASUR survival ${ }^{14}$, what is analysed in this paper is neither UNASUR's performance nor its suitability to cope with regional tensions, but how it has had a say to shape the concept of security in the region. In this sense, it is not an analysis of why UNASUR intervened in some cases and not in others, but what were the main rationales argued to justify its leading role in some of the aforementioned conflicts.

\begin{tabular}{|c|c|c|c|c|}
\hline & $\begin{array}{c}\text { Security as a } \\
\text { derivative concept? }\end{array}$ & $\begin{array}{c}\text { Broader security } \\
\text { agenda? }\end{array}$ & $\begin{array}{l}\text { Beyond State- } \\
\text { centrism? }\end{array}$ & Type of threat \\
\hline $\begin{array}{l}\text { Internal secession } \\
\text { in Bolivia in } 2008\end{array}$ & Yes & Yes & No & $\begin{array}{l}\text { Intra-state } \\
\text { (uti possidetis } \\
\text { iure) }\end{array}$ \\
\hline $\begin{array}{l}\text { Military bases in } \\
\text { Colombia, 2009 }\end{array}$ & No & No & No & $\begin{array}{l}\text { Interstate } \\
\text { ("classical") }\end{array}$ \\
\hline $\begin{array}{l}\text { Venezuela- } \\
\text { Colombia conflict } \\
\text { in } 2010\end{array}$ & No & No & No & $\begin{array}{l}\text { Interstate } \\
\text { ("classical") }\end{array}$ \\
\hline $\begin{array}{l}\text { Police rebellion in } \\
\text { Ecuador, 2010 }\end{array}$ & Yes & Yes & Ambiguous & $\begin{array}{c}\text { Intra-state } \\
\text { (democratic } \\
\text { clause) }\end{array}$ \\
\hline $\begin{array}{c}\text { Paraguayan } \\
\text { impeachment, } 2012\end{array}$ & Yes & Yes & Ambiguous & $\begin{array}{c}\text { Intra-state } \\
\text { (democratic } \\
\text { clause) }\end{array}$ \\
\hline
\end{tabular}

Source: The author, 2019

\footnotetext{
${ }^{14}$ Apart from the 6 members (Argentina, Brazil, Chile, Colombia, Perú and Paraguay) that decided to suspend their membership to UNASUR in August 2018, Colombia and Chile have launched a new regional mechanism, "Prosur", in order to substitute UNASUR.
} 
What has been proved by this quick overview of the regional crises addressed by UNASUR is the different nature of the conflicts as well as the fast-growing relevance of this regional mechanism to play as a valid intermediate and to be considered legitimised to intervene in domestic conflicts -at least in the first years since its creation. In relation to the nature of regional conflicts, it is noticeable how an increasing number of crises were internal and not interstate, which were the traditional ones in terms of security. That reinforced the already mentioned paradox in Latin America where a statist perspective in security was the theoretical mainstream, although intrastate violence was more relevant (and more likely) than interstate conflicts.

Indeed the domestic crises would not have been addressed by an external entity, unless this entity had a remarkable legitimacy recognized for all members. This was the case of UNASUR, from its birth until the escalation of the Venezuelan crisis, where polarization burned every bridge so mediation, such as the one proposed by UNASUR, became futile.

Nevertheless, the argument related to the legitimacy amassed by UNASUR for several years was not a minor achievement. Its capacity to intervene in domestic affairs, mainly in a geographic region such as South America, where Public International Law and, more precisely, the uti possidetis iure principle has been profusely developed, was remarkable. In other words, the traditional South American opposition to foreign intervention and aggressions to their autonomy and/or territory found an exception when talking about a regional entity -not an outer one (Duarte Villa \&Trindade Viana, 2010: 104)- with a powerful recognised legitimacy in its first years of existence.

\section{Conclusions}

In this paper I have tried to analyse the role played by UNASUR in several regional crises from 2008 to 2016-7 in order to see if it fitted into the broader security concept coined and developed by the Critical Security Studies. As mentioned before, the idea of security is a derivative concept which depends on our understanding of the world. Following these CSS shared characteristics, UNASUR, apart from developing a consensus forum to strengthen regional cooperation, consolidating South America as a peace zone and fostering a South American common identity -as underlined by the three main objectives of the CDS-, represented a comprehensive security agenda, i.e., broader than the traditional interstate conflicts. In fact, UNASUR mainly dealt with internal crises affecting democratic stability. Indeed, Ecuadorian crisis in September 2010 was in the origin of the UNASUR democratic clause, which recognised sanctions in case of any coup d'etat in the region. Indeed, this democratic clause was the one applied for the Paraguayan crisis in 2012 and the consequent temporary suspension of Asunción from the UNASUR.

Furthermore, transnational risks have also been addressed by several regional groupings within UNASUR ${ }^{15}$. Therefore, following the objectives of the CDS, regional cooperation did also mean the exchange of information on military purchases to avoid regional mistrust (linked to a traditional rationale of security), as well as coordinated military exercises which foster shared identity and mutual trust among the different actors, or common agreements against organised crime and environmental disasters (thus, closer to a more comprehensive understanding of security).

However, concerning the characteristics stated by Peoples and Vaughan-Williams, the more problematic is the one related to the state-centric approach. In spite of an effort to seek new "referent objects of security" beyond the state -such as the citizen's well-being or the regional community as a whole-, I argue that this element was not really applying in the case of

15 For instance, the "High level working group on management in case of disasters", created in August 2013 after the outcomes produced by the earthquake and tsunami, which affected Chile in March 2013, as well as the "South American Council on citizen security, justice and coordination of actions against Transnational Organized Crime", created in November 2012. 
UNASUR's practices. The aforementioned crises were strictly statist -at least in their originsand, even more important, those crises were addressed by the presidents of the member states of UNASUR, reinforcing the idea that political decisions are adopted from the capitals.

Indeed, even if a regional identity was invoked, the national political agenda and domestic priorities were the ones that had more impact on UNASUR. So, even if national loyalty and regional identity are in permanent tension and they act in a sort of historical struggle between these two rationales (Caballero, 2015:43-60), at the end of the day South American diplomacy is mainly interpresidentialist and each president talks on behalf of his/her own nation-state (Burges, 2017; Malamud. 2003). This national prevalence seems stronger because the one called to be the regional leader, Brazil, was reluctant to pay any cost of being considered a hegemon. In fact, most of the times, Brazilian decisions in regional affairs were closer to be explained by national interests -though not fully satisfactory- rather than seen as regional improvements. In this sense, due to this limited Brazilian view, UNASUR could be understood as a mere way to stabilize the region in order to use it as a springboard to project itself in the international as a global player (Malamud, 2011; Caballero, 2011).

According to this argument, UNASUR was not able to fulfil the CSS requisite concerning the overcoming of state-centric perspective. Insofar as democratic stability could be interpreted as protecting citizen's well-being -so the main beneficiary of this security would be the citizenship or the society as a whole-, it could be argued that the traditional state-centric security was moving to incorporate also the individual, understood as "a relevant object" to be protected. Nevertheless, from the facts analysed here it is proved that, while changes have been taking place in terms of a broader security agenda and the meaning of security as a derivative concept, in the specific case of the state-centric perspective, this statist vision was still the dominant approach concerning security issues in the South American realm. In this sense, one of the main features of Latin American studies on security -statecentrism- ${ }^{16}$ remains the same, mainly due to the fact that "realist assumptions continue to inform the debate on security, even today" (Tickner \& Herz, 2012:105).

\section{References}

AÍN, G.(2012). Multilateralismo y Resolución de Conflictos en Sudamérica, Tesina del Máster de Relaciones Internacionales y Estudios Africanos, Universidad Autónoma de Madrid

ALMEIDA, P. R. (2005). Políticas de Integraçâo Regional no Governo Lula, Centro Argentino de Estudios Internacionales. Workingpaper, 11

AMORIM, C. (2010). Brazilian Foreign Policy under President Lula (2003-2010): an overview, Revista Brasileña de Política Internacional, 53 (special edition), pp.214-240

BATTAGLINO, J. (2008). Transformaciones en la seguridad internacional en la post Guerra Fría: su impacto en América del Sur, Estudios Internacionales, 160, Universidad de Chile, pp.733

BLANEY, D. \& TICKNER, A. (2017). Worlding, Ontological Politics and the Possibility of a Decolonial IR, Millennium Journal of International Studies, 45(3), pp. 293-311

BRICEÑO RUÍZ, J. (2010). La UNASUR ¿Continuum o un nuevo inicio del regionalismo sudamericano? en MARTÍNEZ ALFONSO, L., RAMANZINI JUNIOR, H. \&VÁZQUEZ, M. (coords.). Anuario de la Integración regional de América Latina y el Gran Caribe, 8, pp.103121

\footnotetext{
${ }^{16}$ Tickner \& Herz (2012:103-108) underlined four main features: (i) state-centrism; (ii) parochialism; (iii) expert communities and policy knowledge; and (iv) invisible theory.
} 
BURGES, S. (2017). The Importance of Presidential Leadership for Brazilian Foreign Policy, Policy Studies, 38, pp.277-290

BUZAN, B. \& HANSEN, L. (2009). The Evolution of International Security Studies, Cambridge University Press

BUZAN, B., WAEVER, O. \& DE WILDE, J. (1998). Security: A New Framework for Analysis, Lynne Rienner Publishers, Boulder (USA)

CABALLERO, S. (2011). Brasil y la región: una potencia emergente y la integración regional Sudamericana. Revista Brasileña de Política Internacional (RBPI), 54 (2), Brasilia

CABALLERO, S. (2014). La Unasur a través de los ojos de los Estudios Críticos de Seguridad, Working Paper Instituto de Iberoamérica, Universidad de Salamanca, DT 07/2014

CABALLERO, S. (2015). Identity in Mercosur: Regionalism and Nationalism, Global Governance, 21 (1), pp.43-60, Lynne Rienner Publishers, Jan-Mar

CASE COLLECTIVE (2006). Critical Approaches to Security in Europe: A Networked Manifesto. Security Dialogue, 37 (4)

COX, R. \& SINCLAIR, T. (1999). Approaches to World Order. Cambridge University Press

DE LA FLOR, J. L. (2012). Desarrollos epistemológicos y reconsideraciones del concepto de seguridad en tres Escuelas Europeas de Relaciones Internacionales: Aberystwyth, Copenhague y París, Paper presented at the IPSA Congress, Madrid

DUARTE VILLA, R. A. \& TRINDADE VIANA, M. (2010). Security issues during Lula's administration: from the reactive to the assertive approach, Revista Brasileña de Política Internacional, 53, número especial, Brasilia

HUGHES, C. \& MENG, L.Y. (2011). Security Studies. A Reader, Routledge, New York

KACOWICZ, A. \& MARES, D. (2016). Security Studies and Security in Latin America: The first 200 years, in KACOWICZ, A. \& MARES, D. (Ed.). Routledge Handbook of Latin American Security, Routledge, New York, pp.11-29

KALIL MATHIAS, S., CAVALLER GUZZI, A. \& AVELAR GIANNINI, R.(2008). Aspectos da integração regional em defesa no Cone Sul, Revista Brasileira de Política Internacional, 51 (1), Brasilia

MALAMUD, A. (2011). A Leader Without Followers? The Growing Divergence Between the Regional and Global Performance of Brazilian Foreign Policy, Latin American Politics and Society, 53 (3), pp. 1-24

MALAMUD, A. (2003). Presidentialism and Mercosur: a hidden cause for a successful experience, in LAURSEN, F. (ed): Comparative Regional Integration: Theoretical Perspectives. Aldershot: Ashgate

MUGGAH, R. \& DINIZ, G. (2013). Securing the border: Brazil's 'South America first' approach to transnational organized crime, Strategic Paper, 5, Igarape Institute

NOLTE, D. \& WEHNER, L. (2012). Unasur and the New Geopolitics of South America, Paper prepared for the XXIII IPSA World Congress of Political Science, Madrid

OELSNER, A. (2009). Consensus and Governance in Mercosur: the Evolution of the South American Security Agenda, Security Dialogue, 40, pp.191-212

PEOPLES, C. \& VAUGHAN-WILlIAMS, N. (2010). Critical Security Studies. An Introduction, Ed. Routledge

PROGRAMA NACIONES UNIDAS PARA EL DESARROLLO (PNUD) (1994). Informe sobre Desarrollo Humano. Disponible http://hdr.undp.org/sites/default/files/hdr 1994 es completo nostats.pdf (last access September $26,2018)$ 
RIGGIROZZI, P. \& TUSSIE, D. (2012). The Rise of Post-Hegemonic Regionalism in Latin America, en RIGGIROZZI, P. \& TUSSIE, D, The Rise of Post-hegemonic Regionalism. The case of Latin America, Springer

RODRIGUES, G. \& RODRIGUES, T. (2011). La Unión de las Naciones Sudamericanas (UNASUR) y los nuevos temas de la agenda regional de paz y seguridad: Roles y mecanismos de participación de la sociedad civil, en SERBÍN, A. (coord.). De la ONU al ALBA: Prevención de conflictos y espacios de participación ciudadana, Editorial Icaria/Ediciones CRIES, Barcelona y Buenos Aires

SANAHUJA, J. A. (2007). Regiones en construcción, Interregionalismo en revisión. La Unión Europea y el apoyo al regionalismo y la integración latinoamericana, en "iSirve el diálogo político entre la Unión Europea y América Latina?”, Documento de Trabajo n 15, Fundación Carolina CeALCI

SANAHUJA, J. A. (2011). Multilateralismo y regionalismo en clave suramericana: el caso de Unasur, en Pensamiento Propio, CRIES, 33,115-158

SANAHUJA, J. A. (2014). Enfoques diferenciados y marcos comunes en el regionalismo latinoamericano: Alcance y perspectivas de UNASUR y CELAC, en Pensamiento Propio, CRIES, 39, pp. 75-108

SANAHUJA, J. A. (2019). La crisis de la integración y el regionalismo en América Latina: giro liberal-conservador y contestación normativa, en MESA, M. (coord.). Ascenso del nacionalismo y el autoritarismo en el sistema internacional. Anuario 2018-2019, CEIPAZ, Madrid

SERBÍN, A. (2008). Tres Liderazgos y un vacío: América Latina y la nueva encrucijada regional, Anuario CEIPAZ, 2

TICKNER, A. \& HERZ, M. (2012). No place for theory? Security studies in Latin America, en TICKNER, A. \& BLANEY D. Thinking International Relations Differently, Routledge

WAEVER, O. (2012). Aberystwyth, Paris, Copenhague: the Europeness of new "schools" of security theory in an American field, en TICKNER, A. \&BLANEY D. Thinking International Relations Differently, Routledge

WAEVER, O. (1993). Securitization and Desecuritization, Centre for Peace and Conflict Research, Copenhagen

WILlIAMS, P. (ed.) (2008). Security Studies. An Introduction, Routledge, New York

WOLFERS, A. (1952). National Security as an Ambiguous Symbol, Political Science Quarterly, 67 (4), pp.481-502 
